Богомолець О. В.

\title{
ОБРЯДОВА ПРАКТИКА ЯК ЗАСІБ ЗБЕРЕЖЕННЯ КОЛЕКТИВНОЇ ПАМ'ЯТІ: УКРАЇНСЬКИЙ ВИМІР
}

Мета роботи полягає в експлікаиії традиційної обрядової практики як одного з невіддільних елементів $і$ засобів трансляиї колективної пам'яті украӥнського народу. Для цього запропоноване авторське тлумачення обрядової практики як специфічного різновиду соиіальної практики, щуо характеризується сукупністю формалізованих $і$ стилізованих символічних дій спільноти, спрямованих на збереження усталеного соціального порядку шляхом формування в людини певних ідей і почуттів. Водночас експліковано думку, щуо збереження усталеного порядку відбувається завдяки увічненню міфрів, ушануванню цілої низки історичних подій, героїв $і$ святих. У такий спосіб забезпечується нерозривний зв 'язок із минулим, котре, з одного боку, легітимізує єдність групи в теперішньому, а з другого визначає ї̈ иіннісну систему й культурну самобутність і тим самим сприяє збереженню ијілісності спільноти.

Ключові слова: обрядова практика, обряд, ритуал, колективна пам'ять, релігійна практика, ідентичність.

The purpose of the work is to explicate the ritual practice as one of the inseparable elements and means of broadcasting the collective memory of the Ukrainian people. Therefore, the author proposes her own interpretation of ritual practice as a specific type of social practice, which is characterized by a set of formalized and stylized symbolic actions of the community aimed at preserving the established social order through formation of certain ideas and feelings in a person. Besides, the author presupposes that the settled order is maintained due to the perpetuation of myths, the memory of a number of historical events, heroes and saints. Thus, there is an inextricable link with the past, which, on the one hand, legitimizes the unity of the group at the present time, and on the other - determines its value system and cultural identity and there by contributes to the preservation of the integrity of the community.

Keywords: ritual practice, ritual, collective memory, religious practice, identity.

Цель работы состоит в экспликации обрядовой практики как одного из неотделимых элементов и средств трансляции коллективной памяти украинского народа. Для этого предложено авторское толкование обрядовой практики как специчфической разновидности соииальной практики, которая характеризуется совокупностью формализированных $u$ стилизированных символических действий сообщества, направленньх на сохранение устоявшегося социального порядка путем формирования в человеке определенных идей и чувств. В то же время эксплицирована мысль, что сохранение устоявшегося порядка происходит благодаря увековечиванию мифов, почитанию памяти целого ряда исторических событий, героев и святых. Таким образом обеспечивается неразрывная связь с прошлым, которое, с одной стороны, легитимизирует единство группы в настоящее время, а с другой - определяет ее ценностную систему и культурную самобытность и тем самым способствует сохранению ичелостности сообщества.

Ключевые слова: обрядовая практика, ритуал, коллективная память, религиозная практика, идентичность.

() Богомолець О. В., 2018 
Постановка проблеми. Вивчення традиційної культури, розкриття основних рис i функцій iї соціальних інститутів $\epsilon$ важливою проблемою різних суспільних дисциплін, більшою чи меншою мірою дотичних до культурології. Такий інтерес зумовлений тим, що традиційні інститути створювали, освоювали й передавали зразки поведінки від одного покоління до іншого, акумулюючи в собі основу культурної й ментальної традиції. Відповідно, саме вони закладали підгрунтя для структурування соціального простору й часу, формували ідентичність індивіда, тим самим генеруючи засади творення етнічної картини світу. Остання, попри застороги постмодерністів кінця XX ст. щодо «смерті суб'єкта», а з ним і будь-якої усталеної ціннісної системи, не втратила ані соціального, ані геополітичного впливу. Глобалізація призводить до високого рівня знецінення модерних метанаративів i, відповідно, основ національної ідентичності, поміж тим не зумовлюючи руйнування соціальності як такої. За нових соціокультурних і геополітичних умов, як справедливо зауважує С. Гантінгтон, відбувається «звуження ідентичності» [25, с. 17]. Як наслідок, особливого значення набувають культурні символи, світоглядні концепти й соціальні практики, які сформувалися на локальному рівні. Саме вони забезпечують людину орієнтирами для щоденного життя, формують іiі цінності, визначаючи тим самим iï індивідуальну й колективну ідентичність.

Особливо гостро вказані проблеми проявилися останніми роками внаслідок зростання міграційних потоків. Вони істотно розмили традиційний поділ між внутрішньою колективною сферою життя, яка належить до сфери «свого», i зовнішньою, яку подає соціокультурний простір інших. Тобто, в умовах високого рівня культурного взаємодії відбувається руйнування чіткої демаркаційної межі, а розрізнення «свого» й «чужого», відтак і самоідентифікація, стають більш проблематичними. Унаслідок цього спільнота, з одного боку, опиняється перед ризиком утратити легітимні підстави своєї соціальної єдності, а з другого - проявляє нетерпимість. Остання, як доводить відомий американський учений Дж. Гайдт, $є$ психічною реакцію на загрозу - у цьому випадку - збереженню ментальної самобутності [29]. Тобто, за твердженням ученого, масова міграція у випадках, коли вона не супроводжується асиміляцією, сприймається як «нормативна загроза» усталеному моральному й соціальному порядку.

Особливо гостро проблема культурної й політичної ідентичності проявляється в сучасному українському соціумі. Звісно, тут вона зумовлена не стільки міграцією, як відсутністю дієвої національної стратегії. У поєднанні з маніпулятивною політикою внутрішніх і зовнішніх політичних еліт та низьким рівнем життя суспільства це не тільки істотно підриває легітимність національної ідентичності, а й призводить до появи «нормативної загрози» існуванню групової ідентичності. Така ситуація зумовила зростання суспільної уваги до проблем колективної, i насамперед етнокультурної ідентичності, механізмів її відтворення й легітимації.

Варто зауважити, що розроблення стратегій збереження й трансляції соціального досвіду, а відтак і основ групової ідентичності було незмінним осердям суспільного світогляду на всіх етапах суспільного розвитку. Так, приміром, перші соціальні практики групової консолідації були зафіксовані ще в Рігведі [див.: 17, с. 185-189]. 
Згодом вирішення цієї проблеми зустрічаємо у священних текстах усіх релігійних систем і філософських трактатах різних історичних періодів. У цьому контексті можна згадати «Республіку» Платона, «Нікомахову етику» та «Політику» Арістотеля, «Про державу» Марка Цицерона, «Римські питання» Плутарха чи «Моральні листи до Луцилія» Луція Сенеки. В епоху раннього Середньовіччя цьому питанню присвятив чимало уваги Іоанн Златоуст. Він уважається засновником східнохристиянської літургії, яка ще до розколу християнства на православ'я й католицизм започатковувала соціальну практику для розмежування з аріанами, а пізніше стала основою формування православної ідентичності [21]. Подібним чином відбувалося формування чіткої демаркаційної межі між православною й католицькою церквою, а згодом - католицькою та протестантською.

На перший погляд видається, що вказані відмінності були закладені передусім у віровченні. Між тим таке зауваження було б аж надто передчасним. Досить згадати своєрідність формування української етнокультурної ідентичності в XVI-XVII ст. [5, c. 324]. У цей час, як відомо, проявляється неабиякий спротив тогочасного українського населення (селян, міщан, дрібної та середньої шляхти, православного духовенства) наступу католицизму, що вів до полонізації магнатерії - і це всупереч тому, що остання відкривала для православних чималі особисті перспективи. Відповідно, цілком закономірно постає питання: чому ж так палко українці намагалися зберегти власну релігійну ідентичність?

Зрозуміти причини глибокої прихильності представників традиційної культури до усталеного способу життя можна тільки чітко усвідомивши, що ідентичність у передмодерновій і ранньомодерновій парадигмах, коли відбувалася конфесіоналізація суспільства, мала наперед визначений характер, у тому числі в плані віри. Людина в процесі виховання й обрядової практики отримувала власне місце, роль і призначення в соціумі, який від самого початку був чітко структурований i гармонійно впорядкований - насамперед завдяки ретельному дотриманню родинної обрядової практики [5, с. 34-44]. Відповідно, перехід в іншу, «конкурувальну» конфесію 3 іiі власними обрядовими практиками означав руйнування попереднього усталеного морального й ціннісного порядку. Людина мала відмовитися від усього того, що 3 дитинства визначало спосіб іiі бачення світу й поведінку. Інакше кажучи, окатоличення сприймалося як «нормативна загроза» усталеним релігійно-соціальним практикам. Поза тим, відігравало свою роль і негативне ставлення католицизму до обрядовості народної. Натомість в Україні, краю переважно православному, не спостерігалося, як доводив свого часу В. Антонович, таких страшних і жорстких процесів проти народної обрядовості та знахарства, як у Свропі від початку ХІІІ ст. $[2$, c. 6] (те ж саме, однак, можна сказати й про Велике князівство Литовське, і про Річ Посполиту, у складі яких перебувала Україна). Разом із тим, одна справа православний обряд, якого українці дотримувалися як на родинному, так i громадському рівні (хоча й нерідко змішаний із дохристиянськими елементами), інша - основи православного віровчення, котрі не тільки більшість тогочасних українців, а й священнослужителі знали погано [2, с. 35]. Ця обставина, на наш погляд, помітно знижувала роль православ'я як дієвого чинника формування колективної 
ідентичності.

Не менш актуальною проблема формування / відтворення колективної ідентичності залишалася й у модерну добу. Докорінна зміна способу виробництва зумовила не тільки разючі соціальні трансформації, а й сприяла поступовій десакралізації соціального простору. Руйнування усталеної соціальної системи, спричинене урбанізацією, призвело до формування атомарної особистості, тим самим, 3 одного боку, знецінивши значення традиційних обрядових практик, а 3 другого актуалізувавши необхідність пошуку нових механізмів формування колективної ідентичності.

Руйнування традиційних і постання модерних форм ідентичності зумовлювали необхідність розроблення й нових механізмів особистої й групової ідентифікації. Це й не дивно, адже модерна епоха істотно видозмінила соціальні пріоритети - родина, яка для премодерну й раннього модерну була головною суспільною ланкою i, як справедливо акцентував увагу Е. Тоффлер, визначала соціальну роль кожної людини, стає приватною сферою й виводиться поза увагу суспільного дискурсу [22]. Натомість осердям суспільно-політичного дискурсу стає громадянське суспільство як закономірний, цілком свідомий результат суспільного договору. Обгрунтування цієї теорії такими провідними мислителями новітньої доби, як Гуго Гроцій, Т. Гоббс, Дж. Локк, Ж.-Ж. Руссо та ін., призвело до того, що ніщо у світі вже не могло розглядатися як даність. Навпаки, кожна сторона людського життя відтепер стала завданням, причому таким, що не залишало людині іншого вибору, окрім як узятися за його вирішення, докладаючи для цього всі свої здібності. Унаслідок цього притаманна традиційному світогляду ідея «приречення» поступово змінилася «життєвими планами», доля - покликанням, а вроджена «природа людини» «ідентичністю» [4, с. 179].

Загалом модерна доба відкрила людині нові та привабливі перспективи, які неодноразово звеличувалися таким відомими тогочасними мислителями, як Дж. Піко делла Мірандола, Ж.-Ж. Руссо, І. Кант та ін. Однак поступово оптимізм, зумовлений нескінченними можливостями людини, почав змінюватися більш песимістичними настроями, які вперше були чітко усвідомлені у філософії Ф. Ніцше [16]. Зокрема мислитель, проголошуючи свою відому тезу про «смерть Бога» («Бог помер. Ми вбили його...»), акцентував увагу, що головна мета модерну досягнута - традиційні цінності, так само як і весь метафізичний світ, зруйновані, і відтепер саме людина, а не Бог, є творцем світу, відтак і відповідальність за результати іiі діяльності перекладені саме на неї [24]. Звісно, у період життя та творчості Ф. Ніцше багато положень його філософії не були й навіть не могли однозначно бути сприйняті суспільством. Між тим, з погляду сьогодення його філософія видається пророчою, адже навряд чи в когось виникне сумнів, що сьогодні кожна окрема людина перетворюється на творця не тільки власного, а й колективного життя. За такий умов сутнісна необхідність людини належати до світу інших, на думку американського вченого Б. Яка, реалізується на основі почуття лояльності щодо людей, із якими ми поділяємо щось спільне [28, с. 19]. Звісно, глибина й інтенсивність таких почуттів може істотно варіюватися в різних формах спільноти, визначаючи рівень їхньої 
стабільності.

Зауважимо, що, за твердженням Н. Кривди, найбільш стабільними соціальними групами незмінно залишаються ті, що сформувалися на тлі спільного соціокультурного середовища $[14$, с. 60]. Водночас дослідниця зауважує, що його «культурний вплив відбувається несвідомо i визначається народженням та соціалізацією. Вона змушує індивіда не тільки вчитися рідною мовою, опановуючи водночас культурний та історичний досвід спільноти, а й забезпечує вступ до організації суспільства та його інститутів. Останні, своєю чергою, забезпечують формування цілого спектру вартостей та стереотипів, котрі представники кожної культури вважають «нормальними»» [14, с. 61]. Не останню роль у цьому процесі, як доводить Н. Кривда, відіграє й історія, що представлена у вигляді традицій, історичних свят і пам'ятних днів.

Загалом погоджуючись із висновками української дослідниці, хотілося б звернути увагу на зауваження А. Байбуріна, що колективну єдність забезпечує не тільки традиція, частіше за все представлена у вигляді історичних свят і пам'ятних днів, а цілий спектр типових програм поведінки, котрі регламентують усі сфери життя людини в суспільстві, формуючи тим самим у неї деякі соціально значимі норми [3, с. 37-38]. Водночас учений зауважує, що кожній етнічній культурі притаманні власні, історично сформовані уявлення про значимість певних аспектів поведінки, а отже, своя конфігурація кордону між обов'язковою (типізованою) i вільною (індивідуальною) поведінкою. За таких умов більш значимі сфери поведінки зазвичай відповідають базовим соціальним цінностям групи, а відтак контроль за дотриманням цих стандартів завжди набагато жорсткіший [3, с. 38].

Слід зазначити, що, на глибоке переконання А. Байбуріна, саме ця стереотипна поведінка $є$ запорукою існування спільноти в часі у вигляді самобутньої етнографічної групи. Це зумовлено тим, що в процесі взаємодії із зовнішнім середовищем спільнота накопичує соціально значимий досвід, який передається наступним поколінням у процесі соціалізації. Між тим очевидно, що суспільство не спроможне передати увесь накопичений досвід, відтак воно впорядковує найбільш значимі його фрагменти за допомогою стеоретипізації. Під час цього процесу, продовжує свою думку дослідник, наявна інформація стає не просто сумою корисних знань, а організованим досвідом, який легко транслювати від покоління до покоління. 3 огляду на те що колективна пам'ять не може включати весь досвід, стереотипізація найбільш значимої інформації відкриває можливість для оновлення та новацій [3, c. 38].

Загалом визнаючи правомірність висновків відомого дослідника, хотілося б звернути увагу, що одними з найбільш показових прикладів стереотипної поведінки, на наш погляд, може бути обрядова практика. Володіючи усталеним набором шаблонів, вона може утримувати цілісний образ спільноти навіть тоді, коли відповідні їй вартості втрачають своє соціальне значення, проте продовжують існувати у вигляді звички, що прекрасно продемонстрував П. Коннертон [13]. Між тим дослідник, запропонувавши цілу низку цікавих i актуальних теоретичних положень для вивчення особливостей колективної пам'яті в різних типах суспільств, 
обмежується цілим спектром припущень, котрі потребують істотних уточнень i доповнень, у тому числі й з огляду на конкретно-історичний вимір буття соціальних практик, «пам'яті-звички» та їх впливу на збереження колективної єдності.

3 огляду на сказане, метою нашої роботи є експлікація традиційної обрядової практики як одного 3 невіддільних елементів колективної пам'яті в конкретноісторичному вимірі буття українського соціуму.

Виклад основного матеріалу. Зрозуміти роль обрядової практики в процесі збереження колективної пам'яті неможливо без чіткого розуміння змісту цього феномена. Останній, попри широке використання в науковій літературі, наразі не має чіткого концептуального окреслення, а відтак може позначати відмінні за своїм змістом і функціональним призначенням феномени. Одним із небагатьох винятків у цьому контексті може бути дефініція Н. Сафонової, котра розглядає обрядову практику як «механізм, що формує відносини всередині суспільства, зберігаючи потребу людей в насичених смислами колективних діях, орієнтуючи водночас суспільство на базові ціннісні установки» [20, с. 56]. Інакше кажучи, дослідниця розглядає обрядову практику як засіб регулювання поведінки, критерій оцінки людиною значимої події.

Звісно, наведене вище визначення має право на життя i, що найголовніше, значною мірою розкриває роль обрядової практики в суспільному житті. Між тим Н. Сафонова залишила поза увагою змістове наповнення обрядової практики. Її, на наш погляд, варто розглядати як специфічний різновид соціальної практики, зміст котрої можна розкрити тільки за умови усвідомлення своєрідності обряду як соціокультурного феномена. Проте, як свідчить сучасний інтелектуальний дискурс, це досить складна й неоднозначна проблема. У численних зарубіжних та українських наукових працях, з одного боку, чітко проглядається інтенція на ототожнення обряду з ритуалом. Такий підхід є цілком закономірним з етимологічного погляду. Як відомо, слово ритуал походить від латинського ritus, яке позначало урочисту церемонію, присвячену події, що відбувається із використанням цілого спектру обрядових (ritualis) дій. Цілком очевидно, що в межах традиції, котра постала на тлі латинізованої культури, ототожнення обряду й ритуалу є цілком закономірним, і тут це поняття використовується для позначення деякого стилізованого та формалізованого набору дій, які зазвичай мають символічну цінність, визначену релігією чи традиціями суспільства [1].

Натомість в українській інтелектуальній традиції для позначення стереотипних колективних дій, що мають символічний характер, використовуються два терміни навіть попри те, що дослідники зазвичай уникають чіткого їх розмежування. На наш погляд, така ситуація $\epsilon$ цілком закономірною. Вона зумовлена нерозвиненістю категоріального апарату українського соціогуманітарного дискурсу. У підсумку цього семантичні рецепції давньоруської мови призводять до змістової невизначеності цілого спектру соціокультурних феноменів. 3 огляду на це видається цілком доречним нагадати, що давньоруській мові слово «обряд» семантично споріднене зі словами «наряд» («одяг») та «обряжати» («одягати»), тобто надавати певного вигляду згідно з домовленістю або загальноприйнятим порядком [26]. У цьому контексті 
можна згадати звичай «наряджати» наречену у весільний одяг, заплітати відповідним чином волосся тощо. Ці дії мають символічний характер, який має нерозривний зв'язок із традицією й звичаєм - так роблять, бо так прийнято робити. У цьому випадку обряд не має жодної вказівки на зв'язок із божественним. Він радше постає механізмом ствердження освячених традицією та, відповідно, соціально значимих життєвих станів людини. Так, наприклад, розлога весільна обрядовість спрямована допомогти нареченим усвідомити зміну соціального статусу. Його ж легітимність засвідчують присутні на весіллі члени соціуму. Натомість поховальна обрядовість плакальниці, тризна (обід), читання молитов тощо - може мати подвійний соціальний контекст. 3 одного боку, спільнота проводжає померлого до «іншого світу», або, як зауважував I. Огієнко, - іншого дому [15, с. 124], намагаючись водночас сприяти його подальшому благополуччю, яке в християнізованій українській культурі асоціювалося 3 досягненням «Царства Божого». 3 другого боку, спільнота у стилізованій формі вчиться проживати життя без померлої людини. Особливо чітко ця тенденція проглядається в практиках, які здійснюються в домі померлого після поховання. Як приклад можна згадати воду й скибочку хліба, які 40 днів ставлять на вікні для душі померлого, жалобний одяг, поминальні дні тощо. Усе це засвідчує стан переходу, тісно пов'язаний із набуттям нового соціального статусу осиротілих людей. Жінка стає вдовою, чоловік - удівцем, а це означає, що їхній соціальний статус істотно змінюється. Вони набувають нових соціальний ролей, а часто навіть починають виконувати в родині й суспільстві нові функції.

Звісно, зосереджуючи увагу на соціальному значенні української родинної практики, можна навести ще безліч прикладів, котрі дають можливість усвідомити, що в давньоруській, а згодом i українській культурі обряд розглядався як послідовність експресивних дій, головним завданням яких було збереження соціального порядку. Показово, що останне позначалося словом «чин», яке означало порядок, статут, устав або прийняту послідовність дій (у тому числі й в обряді) [10]. 3 огляду на це, а також на зауваження М. Поповича про індоєвропейське коріння української культури $[19$, с. 7], можемо припустити, що слово «чин» використовувалося для позначення усталеного соціального порядку, збереження якого поставало головною функцією обряду. Наше припущення, звісно, може зумовлювати дискусії з огляду на те, що в українському інтелектуальному дискурсі прийнято розглядати обряд, 3 одного боку, як «десакралізований ритуал, який включає в себе традиційні дії, супроводжує важливі моменти життя і діяльності людини та людської спільноти (обряди, пов'язані з народженням, зі смертю, 3 переходом члена спільності в іншу якість, наприклад, обряди ініціації; сімейні, календарні обряди), за допомогою яких стверджується соціальна значимість життєвих станів членів спільноти (етносу)» [27], а з другого - як «од віку» встановлений Богом, першопредками тощо порядок дій для досягнення певної мети [11]. Натомість ритуал тлумачиться як сукупність формалізованих дій, які досягають особливої церемоніальності завдяки високому рівню формалізації та стилізації [11]. Подекуди ж зустрічається твердження, що ритуал - це сукупність обрядів, що супроводжують релігійний акт [23, с. 15-16], а подекуди, що обряд - це сукупність ритуалів [6, с. 38- 
42].

На наш погляд, жодне 3 вищенаведених визначень не може розглядатися як задовільне, адже в кожній дефініції обряду наявна апеляція до ритуалу й навпаки. Окрім того, і обряд, і ритуал позначають сукупність стилізованих і формалізованих дій, спрямованих на досягнення певної соціальної та / або релігійної мети. 3 огляду на це, на наш погляд, цілком доречно нагадати індоєвропейське коріння слова «ритуал», котре, за твердженням Т. Єлізаренкової, походить від слова «рита» (Rta-), котре як дієприкметник означало «відповідний, правильний», а як іменник - «закон», «порядок», «істина», «священний обряд» i «жертвоприношення» [9, с. 13-14] (порівняйте 3 англійським right або 3 німецьким richtig). Уперше це слово зустрічається в давньоіндійських гімнах богам - Рігведі. Там, за словами дослідниці, воно означало «закон колообігу всесвіту, який регулює правильне функціонування космосу i життя... Все повторюється, i, дотримуючись закону «рита», людина відтворює циклічність космічних явищ в циклічності ритуалу, підтримуючи тим самим порядок у космосі і в людському суспільстві, i тим самим створюючи умови для нормального та успішного життя» (цит. за [9, с. 13-14]). За умови визнання правомірності тверджень Т. Слізаренкової, розрізнення між ритуалом і обрядом утрачають будь-який сенс. Тому видається цілком доречним визнати синонімічність ритуалу й обряду у випадках, коли вони розглядаються як іменники, що позначають сукупність формалізованих і стилізованих дій символічного характеру, спрямованих на збереження усталеного соціального порядку.

Експлікуючи своєрідність обрядових дій, не можна оминути увагою зауваження П. Коннертона, що обряд не обмежується часовими межами його виконання [13, c. 75]. Звісно, учений визначає, що він відбувається зазвичай у спеціально відведеному для цього місці й точно призначений час i, що цікаво, частіше за все спрямований означити початок або кінець. У цьому контексті досить показовою може бути родинна обрядова практика українського народу, а саме сукупність обрядів, які супроводжують народження дитини. Так, приміром, надзвичайно показовим може бути обряд запеленання дитини в батькову сорочку. Він, як стверджує Марко Грушевський, символізує визнання батьком дитини своєю [8, с.42]. Після цього дитина стає членом батьківської родини. Натомість обряд родин, які відбуваються в той же день, коли народилася дитина, хоча, зазвичай, не відзначаються великою кількістю гостей, з одного боку, слугує свідченням набуття нового статусу батьками дитини, а $з$ другого - засвідчує й легітимізує появу нового члена спільноти.

Подібні інтенції можна прослідкувати і в поховальній обрядовості, і в обрядах, пов'язаних із проводами чоловіків на військову службу, і у весільній обрядовості. У кожному 3 цих обрядів одночасно стверджуються кінець і початок. Такий же сенс мають обряди й звичаї, пов'язані з господарською діяльністю. Мабуть, найбільш показовим прикладом буде календарний рік пасічника. Попри те що сьогодні відсутні чіткі відомості щодо його язичницького коріння, усе ж привертає увагу, що винесення вуликів із зимівників, яке відбувалося «на Зосиму» (17/30 квітня), означало прихід теплих днів і відродження життя природи. Натомість, починаючи 32 жовтня, тобто 
«від Саватія», природа починала швидко завмирати. У цей час уже міг випасти перший нетривалий сніг - він знаменував прихід зими, тобто закінчення одного природного циклу й початок іншого [5, с. 256].

В усіх згаданих нами обрядах чітко демонструється ідея переходу від одного стану до іншого, які репрезентуються через кінець і початок. Між тим саме в цій інтенції обрядових практик закладається проекція майбутнього. Як справедливо стверджує П. Коннертон, «обряди наділяють смислом цілий спектр подальших, вже не-ритуальних дій і вчинків, усе життя спільноти» [13, с. 75]. Інакше кажучи, обряди мають властивість формувати систему цінностей і наділяти життя його учасників смислом.

Тут цілком доречно звернути увагу на смислове поле українського обряду родин. Першим, що тут упадає в око, є формування системи родинної ієрархії. Вона відтворюється через послідовність розміщення гостей за столом, а також повитухи, котра клопочеться біля печі, але за стіл ніколи не сідає. Зокрема на покуті, як свідчить Марко Грушевський, сідає зазвичай найпочесніший гість і батько, біля нього сідають й інші гості. Показово, що за обідній стіл по народженню дитини сідають усі дорослі члени родини, у тому числі й породілля - вона зазвичай розміщується 3 краю стола, однак діти та неодружені брати та сестри в цей час за стіл не сідають [8, с. 52-55]. Інакше кажучи, родинний стіл відіграє своєрідну експресивну функцію. Він відображає громаду як рівних і водночас родинну ієрархію. Ця інтенція особливо чітко проглядається у звичаї подавати частування спочатку батькові, а потім уже решті присутніх.

В окремих випадках частування може спочатку подаватися гостю. Цей звичай $є$ рецепцією давніх язичницьких вірувань, що гість здатний принести гостця демонічну істоту, яка вселяється в людину, спричиняючи їй недугу. Хай там як, але, 3 огляду навіть на окремі аспекти родильної обрядовості, маємо всі підстави говорити, що обряд впливає на формування світоуявлення людини, у межах якого формується иіi місце у світі (це блискуче показав К. Гірц [7, с. 105]). Водночас обряд визначає цілий спектр необрядових дій i тим самим закладає фундамент для формування етнографічної своєрідності спільноти.

Збереження ж сформованого під час історичного розвитку самобутнього етнографічного простору, особливо в неписемних традиційних культурах, як цілком резонно зауважив П. Коннертон, відбувається завдяки постійному повторенню обрядів [13, с. 75]. У такий спосіб формується своєрідний сакральний зв'язок із минулим. Обряди, зокрема, постають увічненням міфів, що вплинули на становлення самобутнього культурного простору. Тут можна згадати українську різдвяну обрядовість, яка, попри істотні зміни в релігійному світогляді, збереглася незмінною аж до нашого часу. У цьому сенсі, мабуть, найбільш показовим є колядування, яке в язичницькій культурі було своєрідним ритуальним дійством, що здійснювалося на свято Коляди. Воно символізувало народження нового сонця, а 3 ним і нового життєвого циклу. У давній культурі в цей день учасники обрядового дійства відвідували домівки членів спільноти й виконували замовляння на добробут в наступному році. Звісно, у період християнізації змістовна частина колядування дещо 
видозмінилася, однак сам обряд і його спрямованість залишилися практично незмінними. Подібними інтенціями також характеризуються народні гуляння на Івана Купала, а в окремих регіонах - і на Великдень, або Паску.

Поряд з обрядами, спрямованими увічнити міфи, існують і такі, що спрямовані на вшанування пам'яті про події, які сталася в певний історичний період, а також дні пам'яті святих чи героїв, які відіграли непересічну роль у житті спільноти. Зауважимо, що обряди, пов'язані з ушануванням пам'яті, не обов'язково мають релігійне спрямування, а широко поширені в секуляризованій культурі. У цьому контексті цілком доречно згадати 8 травня - День пам'яті та примирення, коли вшановують пам'ять жертв Другої світової війни. Між тим церемоніальні акти цього вшанування мають глибоке аксіологічне значення. Вони нагадують про страшні злочини, здійснені в цей період, і наголошують на необхідності прощення та примирення. Крім того, цей день $є$ символом єдності й жертовності, адже практично кожна українська родина осиротіла від утрати рідних і близьких людей. Біль утрати й пам'ять про жертовну відданість рідних і близьких рідній землі перетворюється в механізм консолідації суспільства. Його, до речі, тривалий час дуже вправно використовувала Росія для збереження свого впливу на українське суспільство. Загалом же церемоніальні акти в День пам'яті та примирення мають чітку спрямованість у майбутнє - вони формують гуманістичні ідеали, заразом застерігаючи суспільство від насилля й злочинів. Натомість церемонії 9 травня - Дня Перемоги - символізують силу й міць суспільства, надихаючи його на майбутні перемоги на ниві добробуту та миру.

Звісно, як 8, так і 9 травня - це інтернаціональні події, здатні закладати фундамент для формування ширших, порівняно 3 етносом і нацією, колективних спільнот. Натомість для збереження національної й етнічної ідентичності більше значення мають дні пам'яті, які мають чітко виражений етнічний характер. Як приклад можна згадати вшанування пам'яті Богородиці Покрови, яке в сучасній Україні $\epsilon$ загальнонаціональним святом. На наш погляд, воно надзвичайно красномовно розкриває нерозривний зв'язок українського народу 3 минулим, водночас маючи чітку інтенцію в майбутнє. 3 одного боку, ушанування Богородиці Покрови тісно в'яжеться 3 давньою релігійною традицією - Богородиця Покрова (День пам'яті 14 жовтня) - це символ заступництва, а відтак і стабільності. Її глибоке й щире вшанування могло мати давнє язичницьке коріння, оскільки Покрова - це символ завмирання природи, земля покривається листям i першим снігом, знаменуючи тим самим закінчення сільськогосподарських робіт. Зима - це сон, який у язичництві часто ототожнювався зі смертю, після якої приходить новий життєвий цикл. Крім того, від того, яким буде сніговий покров узимку, залежали врожаї наступного року. 3 огляду на віру у взаємну відповідність космічних і соціальних процесів у язичницькій культурі, після Покрови розпочинався весільний період, обряди котрого символізували завершення періоду дівування чи парубоцтва й відродження в новій іпостасі родини, створення якої $\epsilon$ закономірним етапом загального колообігу життя та смерті.

Давні українські вірування згодом отримали своє продовження й розвиток у 
християнізованій культурі в образі Богородиці Покрови, яка була символом заступництва і в життєвих, і в громадських справах. Ця інтенція чітко відобразилася у великій кількості варіативних образів Богородиці Покрови, які вшановувалися українцями всіх верств і прошарків. Особливого ж ушанування Богородиця Покрова набула в середовищі козацтва, котре вважало іiі не тільки власною, а й усієї України заступницею й покровителькою. Очевидно, що ідея захисту й покровительства була надзвичайно близькою українцям, котрі постійно потерпали від чужоземних утисків. Тому поступово Покрова Богородиця перетворилася на національний символ [5, c. 380]. Сьогодні ж іiі вшанування збігається 3 Днем захисника України. Це дає підстави говорити про комеморацію історичного й релігійного символу відповідно до соціокультурних і світоглядних запитів часу.

На відміну від вшанування Богородиці Покрови, обрядові практики, пов’язані $з$ ушануванням святого Миколая та Великодня, не набули нового символічного звучання. Відзначення цих свят має чітку інтенцію на утвердження в суспільній свідомості історичної спадковості української культури, що, звісно, є вагомим чинником для збереження колективної єдності спільноти. Указана практика особливо чітко проглядається у випадках відродження колективної пам'яті й культурної самобутності в тих регіонах, котрі в радянський період були деетнізовані. Приміром, останніми роками неабиякої популярності набувають акції відродження колективної пам'яті й насамперед обрядової практики на Сході України, які здійснюються творчими колективами західних регіонів з метою повернути їм утрачену ментальну самобутність.

Поряд із громадською й родинною обрядовими практиками неабияке значення для увічнення пам'яті про зв'язок із минулим мають релігійні практики. Звісно, їхнє символічне значення має універсальний, наднаціональний характер, а сама практика, як цілком справедливо зауважував Р. Раппопорт, спрямована на формування незаперечного внутрішнього відчуття єдності зі Священним, або ж, говорячи іншими словами, переживання нумінозного [30, с. 393]. Попри це, як справедливо зауважував свого часу I. Огієнко, православ'я відрізняється від католицизму своїм національним виміром. А тому, продовжує свою думку вчений, кожна «православна церква з бігом віків виробляє своє власне розуміння канонів, свою власну місцеву традицію, власну відправу богослужб, власні свята й т. ін. Наприклад, свято Покрови 1 жовтня [14 жовтня за новим стилем - уточ. наше] для Української Церкви - велике свято року, для Церкви Російської - звичайне свято, а для Церкви Грузинської такого свята зовсім нема. Ось через це маємо справді церкви і Українську, Російську, Грузинську й т. д., а не церкви українського, російського, грузинського й інших народів» [18, с. 91].

Зроблене I. Огієнком зауваження, на наш погляд, надзвичайно важливе для розуміння ролі релігійної обрядовості не тільки для збереження колективної пам'яті національної спільноти, а й для формування іiї самобутньої культури. Досить показовим $є$ зауваження мислителя, що Українською церквою «у чині хрещення допускалося крім погружения й обливання. На вінчанні молоді конче присягали, а без цієї присяги шлюб не був дійсний... Українське повір'я про те, що померлий на Великдень чи святого тижня взагалі йде до раю, знайшло свій вираз і в требниках 
київського видання навіть XIX віку... Було багато місцевих звичаїв, таких, як освячення квіток на Маковея 1 серпня [14 серпня за новим стилем - уточ. наше] або плодів на Спаса 6 серпня» [18, с. 100].

Звісно, усі вищезгадані релігійні практики, так само як і дні пам'яті святих, мають універсальний характер. Водночас у них чітко проглядається орієнтація на зв'язок із минулим саме української спільноти, що, без сумніву, сприяло утвердженню свідомості колективної єдності. Особливо чітко ця інтенція простежується в процесі формування етнографічної своєрідності українських регіонів. Її, на наш погляд, великою мірою забезпечило церковне відродження, розпочате митрополитом Петром Могилою. Чільне місце в цьому процесі відігравала розпочата ним діяльність із популяризації та вшанування чудотворних образів. Зазвичай найбільш шанованими були ті чудотворні ікони, які розміщувалися в місцевих монастирях. Їхнє духовенство всіма можливими засобами намагалося підносити чудотворні ікони, тим самим привернувши увагу до них якомога більшої частини населення [5, с. 209]. Цьому сприяли й іконописні ремісничі осередки, а згодом і народні іконописці-самоуки. Створені ними численні копії чудотворних ікон розходилися по церквах і домівках, у підсумку чого формувалися регіональні релігійні практики вшанування окремих святих. Звісно, це могло істотно гальмувати процес усвідомлення всеукраїнської єдності, але зберігало етнографічну самобутність регіону.

Висновки. На основі зазначеного вище доходимо висновку, що обрядова практика - це специфічний різновид соціальної практики, яка характеризується сукупністю формалізованих i стилізованих символічних дій спільноти, зазвичай спрямованих на збереження усталеного соціального порядку шляхом формування в людини певних ідей i почуттів. Завдяки тому, що обрядова практика має формалізований, стилізований i, що найважливіше, повторюваний характер, котрий проявляється через ушанування певних історичних події, пам'ятних днів чи героїв, вона має чітку інтенцію, з одного боку, на увічнення зв'язку з минулим, а відтак відіграє важливу роль у збереженні колективної пам'яті, а з другого - формування ціннісної системи спільноти, тим самим сприяючи збереженню єдності спільноти.

3 огляду на сказане, важливим і перспективним в умовах розмивання української культурної ідентичності видається дослідження, популяризація обрядових практик, яка буде супроводжуватися комеморацією їх символічної частини. Така діяльність, на наш погляд, може стати вагомим чинником відродження етнокультурної ідентичності українці, що, без сумніву, сприятиме суспільній консолідації.

\section{Література:}

1. Адоньева С. Б. Ритуал, он же - обряд. Разговор об определениях // Персонал-Микс, 2007. Вып. 6. URL : http://www.folk.ru/Research/adonyeva_ritual_2007.php?rubr=Research-articles

2. Антонович В. Чари на Україні. Львів : друк. Наук. т-ва імені Шевченка, 1905. 78 с.

3. Байбурин А. К. Этнические аспекты изучения стереотипных форм поведения и традиционная культура // Советская этнография, 1985, Вып. 2. С. 36-46.

4. Бауман 3. Индивидуализированное общество. М. : Логос, 2005. 390 с. 
5. Богомолещь О. Українська домашня ікона : монографія. Київ : Видавничий дім Дмитра Бураго, 2017. $520 \mathrm{c}$.

6. Бондырева С. К., Колесов Д. В. Традиции: стабильность и преемственность в жизни общества. М. : Издательство Московского психолого-социального института; Воронеж: Издательство НПО «МОДЭК», 2004. $280 \mathrm{c.}$

7. Гіри К. Інтерпретація культур: вибрані есе. Київ : Дух і Літера, 2001. 542 с. $253 \mathrm{c}$.

8. Грушевський М. Дитина у звичаях і віруваннях українського народу. Київ : Либідь, 2006.

9. Емельянов В. В. Ритуал в Древней Месопотамии. СПб.: Азбука-классика; Петербургское востоковедение, 2003. $320 \mathrm{c}$.

10. Зведений словник застарілих та маловживаних слів // Літопис. URL: http://litopys.org.ua/rizne/zvslovnyk.htm

11. Каитова Ж. Обряды и ритуалы // Культуру в жизнь. URL :http://culture-intolife.ru/kaitova_obriady_i_ritualy/

12. Кондратович И. История Подкарпатской Руси для народа. Ужгород : книгопечатня акційн. т-ва «УНІО» в Ужгороді, 1925. 120 с.

13. Коннертон П. Як суспільства пам'ятають. Київ, 2004. 184 с.

14. Кривда Н. Ю., Сторожук С. Культурна ідентичність як основа колективної єдності // International Journal of Innovative Technologies inSocialScience 4(8). 2018, Vol.2. C. 58-63.

15. Митрополит Іларіон (Огієнко). Дохристиянські вірування українського народу. Київ : Обереги, 1994. $424 \mathrm{c.}$

16. Ницше Ф. Человеческое, слишком человеческое. URL : http://www.e-reading.club/book.php? book $=41879$

17. Овсянико-КуликовскийД. Н. К истории культа огня у индусов в эпоху Вед; Основы ведаизма: Культы огня и опьяняющего напитка. М. : Книжный дом «Либроком», 2012. 186 с.

18. Огієнко I. Українська церква : нариси 3 історії укр. православ. церкви. У 2 т. Т. 1. Прага : Вид-во Ю. Тищенка, 1942. 236 с.

19. Попович М. Нарис історії культури України. Київ : АртЕк, 1998. 728 с.

20. Сафонова $H$. Традиционная обрядовая культура как механизм сохранения этнокультурной идентичности // Вестник культуры и искусств. 2016, (3 (47)). С. 55-59.

21. Taфm P. Византийский церковный обряд. Краткий очерк. URL : https://azbyka.ru/otechnik/Pravoslavnoe_Bogosluzhenie/vizantijskij-tserkovnyj-obrjad-kratkij-ocherk/\#0_2

22. Тоффлер Э. Третья волна. URL : http://royallib.com/read/toffler_elvin/tretya_volna.html\#246738

23. Угринович Д. М. Обряды. За и против. М. : Политиздат, 1975. 178 с.

24. Хайдегzер M. Европейский Нигилизм // Библиотека Гумер. URL : http://www.gumer.info/bogoslov_Buks/Philos/Heidegg/EvrNig_02.php

25. Хантингтон С. Кто мы? Вызовы американской национальной идентичности. М. : АСТ: Транзиткнига, 2004. 635 [5] с. all.shtml

26. Церковные обряды // Азбука веры. URL: http ://azbyka.ru/tserkov/bogosluzheniya/5g8_11-

27. Чернявская Ю. Народная культура и национальные традиции // Библиотека Гумер. URL : http://www.gumer.info/bibliotek_Buks/Culture/Chern/15.php

28. Як Б. Национализм и моральная психология сообщества. М. : Изд-во Института Гайдара, 2017. $520 \mathrm{c}$.

29. Haidt J. When and Why Nationalism Beats Globalism. Availableat : https://www.the-americaninterest.com/2016/07/10/when-and-why-nationalism-beats-globalism/

30. Rappoport R. A. Ritual and Religion in the Making of Humanity. Cambrige University Press, 1999. $557 \mathrm{p}$. 


\section{Olga Bogomolets}

\section{RITUAL PRACTICE AS MEANS FOR COLLECTIVE MEMORY CONSERVATION: UKRAINIAN VIEWPOINT}

Developing the strategies for conserving and rendering the social experience, and hence the basis of group identity, was unchangeable corner stone for social outlook at all stages of social development. In the meantime, it is acquiring a special significance in recent years, primarily because the globalization substantially undermines the basics of national identity, thereby causing an increase of public attention to the problems of the collective, and above all, ethnocultural identity, the mechanisms of its reproduction and legitimation.

These problems are especially topical for modern Ukrainian society, which, on the one hand, is the fruit of a civilizational split and, on the other hand, of the internal and external political elites manipulative policy and low living standards.

To preserve its political boundaries, the society requires not only economic stability, but also new, more effective mechanisms and strategies for social consolidation. The latter, as shown by A. Bayburin and P. Conner, can effectively be provided by thoroughly developed or historically formed spectrum of typical behavior programs that regulate all spheres of human life in society, thus forming some socially significant norms. In other words, according to the above-mentioned researchers, it is stereotypical behavior that guarantees a community existence in time as some distinct ethnographic group.

One of the most prominent examples of stereotyped behavior is ritual practice. Possessing the established set of behavior patterns, it is able to maintain the community's accomplished image even when its proper values lose their social significance, but continue to exist as a habit. Thus, this work highlights the role of traditional ritual practice in the process of forming the modern Ukrainian identity. In particular, the idea is defended that ritual practice is not only an inseparable element of people's collective memory, but also the means of forming the group identity, which is perfectly confirmed by Ukrainian family ritual practice's pecularities.

It is revealed that the timeless and expressive character of ceremonial actions has a decisive importance for preserving the group identity and the established social order. Despite of the irrecurring nature, which provides the connection to the past, it always means the beginning and the end at the same time. An illustrative example in this context may be wedding, maternity and economic ceremonies. All of them are permanent and repetitive transitions from one state to another. At the same time, ritual practice gives the sense to the whole spectrum of non-ritual actions, thus defining the future's perspective.

In general, the work considers ritual practice as a specific kind of the social one. It is characterized by the set of formalized and stylized symbolic actions of the community, usually aimed at preserving the established social or by means of forming certain ideas and feelings in a person. In the course of research work, it was emphasized that the formalized, stylized and, most importantly, the repeatable nature of the ritual practice, which manifests itself through commemoration of certain historical events, memorable days or heroes, ensures its clear intention to perpetuate the connection with the past. Thus, it plays an 
important role in the process of preserving the collective memory. On the other hand, the formation of the community's value system is taking place, thus contributing to the preservation of its unity.

Considering the consolidating significance of the ritual practice in terms of blurring the Ukrainian cultural identity, the studying and popularization of ritual practices seems to be important and promising, which would be accompanied by commemoration of their symbolic part. Such an activity could become a significant factor in the revival of the ethnocultural identity of the Ukrainians and promote social consolidation.

Богомолець Ольга Вадимівна - доктор медичних наук, професор, Верховна Рада України, народний депутат України.

Bogomolets Olga Vadymivna - Doctor of Medical Sciences, Professor, Verkhovna Rada of Ukraine.

ORCID: 0000-0002-1476-5819

Надійшла до редакції 29.05.2018. Розглянута на редколегії 25.06.2018.

\section{Рецензенти:}

Доктор філософських наук, завідувач кафедри філософії Національного аерокосмічного університету ім. М.С. Жуковського «ХАІ» Чернієнко В.О.

Кандидат філологічних наук, доцент, доцент кафедри документознавства та української мови Національного аерокосмічного університету ім. М.С. Жуковського «ХАI» Медведь О.В. 